\title{
Contract Breach and Payment for Environmental Services: A Case from the Kulekhani III Hydroelectric Project in Nepal
}

\section{Dr. Khet Raj Dahal and Nabina Rai}

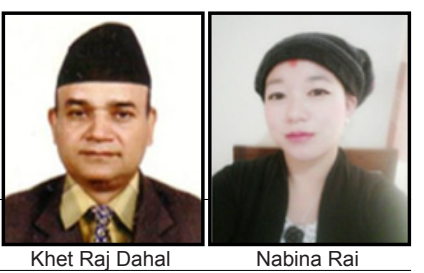

Abstract: This study was conducted in 2014. The main objective of this study was to find out the cause of contract breach and Payment for Environmental Services (PES) of Kulekhani III Hydroelectric Project (Kulekhani III HEP). PES is a relatively new concept but it is important as it forces employers, contractors, and local residents of a hydropower project to take a fresh look to support a successful construction effort without causing unnecessary environmental damage. Research findings from responses of local people regarding PES programs, in their respective areas of Kulekhani III Hydroelectric Project have been presented. Hydropower construction is extremely complex works, reliant on a host of individual parties and processes to come together to bring a project to fruition. In every context of Nepal, there are additional challenges in terms of adhering to contractual terms and negotiating governmental and donor agencies requirements for proper construction of hydropower project. In the first half of this paper, it has been explored as a case study in the form of Kulekhani III HEP to provide a record of many overruns the contractor experienced. The project became delayed. There were many causes behind the project delay of Kulekhani III HEP. However, permit for tree clearance for access road and untimely payment for contractors are the major ones.

Keywords: Contract breach, Payment for Environmental Services (PES), community forest, hydroelectric project, Nepal.

\section{Introduction}

Construction of hydroelectric projects are complex Wworks that require a challenging combination of human resources, material and money. And ultimately all of which requires substantial planning and contingency for time and transportation (Pandey, 2013). These constructions are complicated further by the presence of donor agencies and their requirements for building and clearance of the project. However, despite these challenges, the business of hydropower is very attractive because it gives good returns of investment and also represents an addition to any energy portfolio for its free production potential (Karmacharya, 2008). This has sparked a global surge in hydropower production. As these projects appear around the world, unfortunately, so does the potential for risk and malfeasance regarding the financing and environmental clearance of hydropower project (Karmacharya, 2008).

The difficulties of projects due to time bound often exceed the planning and operational ability of many contractors. Mahamid (2011) found that many projects that are awarded to the contractors are not able to meet their stated time and financial goals. There are additional concerns related to currency exchange values, available resources, errors in cost estimation, and safety in construction area (Abu Ed, 2012).

Among many contractors, 40\% factors affecting the construction contracts termination are related to economic issues, $30 \%$ are related to political issues, and 30\% are related to other factors (Abu Ed, 2012). Contract Act, 2000, was Promulgated with the idea that many of these challenges could be lessened if hydropower construction proceeded with a richer understanding of breach of contract rules. The Contract Act lays out multiple stipulations under which a contract may be forfeited if one of the agreement parties fails to meet stated expectations, and guarantees financial reparation for the aggrieved party in the event of those failures.

Breach of project studies is becoming more common globally. Dessa (2003) finds in Ethiopia that in many cases both parties (contractors and clients) breach an agreed-upon contract either for late issue of drawings, delay in site handover, late approval of payment certificates, delay in payment for complete works, change in the scope of the work in mid-contract, and delay in delivering resources. These infractions often occur because contractors attempt to win bids without having proper knowledge of their potential and the competitive bidding.

PES is a concept which deals with the economic support and plans to conserve environmental services by providing economic incentives to contractors who will be responsible for managing ecological services before and during construction. As it is a relatively new concept, PES is facing new challenges with its introduction to Nepal (Khatri, 2009).

PES has received considerable attention in recent years as a way of creating incentive for managing natural resources, addressing livelihood issues for the rural poor people, and providing sustainable financing for protected areas. The basic idea of PES is that those who provide environmental services by conserving natural ecosystems should be rewarded (WWF, 2006).

There are many such challenges for PES. Despite these challenges, several organizations in Nepal have embraced PES for application in watershed management. For example, PES is in practice at the Kulekhani III HEP area in Makwanpur district of Nepal. Similarly, the IUCN-Nepal, and the International Centre for Integrated Mountain Development (ICIMOD) instituted PES concepts in the Shivapuri Watershed for drinking water services (Khanal \& Paudel, 2012). At present, PES is being used as development tool to eradicate poverty 
and to conserve the existing environment. PES can also be used for rearranging income, especially at the local level (Mahamid, 2011). In many cases, the design of PES programs can be improved by outlining baselines, calculating conservation opportunity costs, customizing payment modalities, targeting agents with convincing land claims and threats to conservation in ecosystem services (Wunder, 2007).

\section{Materials and Methods}

In this study, breach of contract and PES the Kulehani III HEP has been examined. This project has been categorized as "national priority" by the National Planning Commission, Government of Nepal (GoN) (ESSD, 2014).

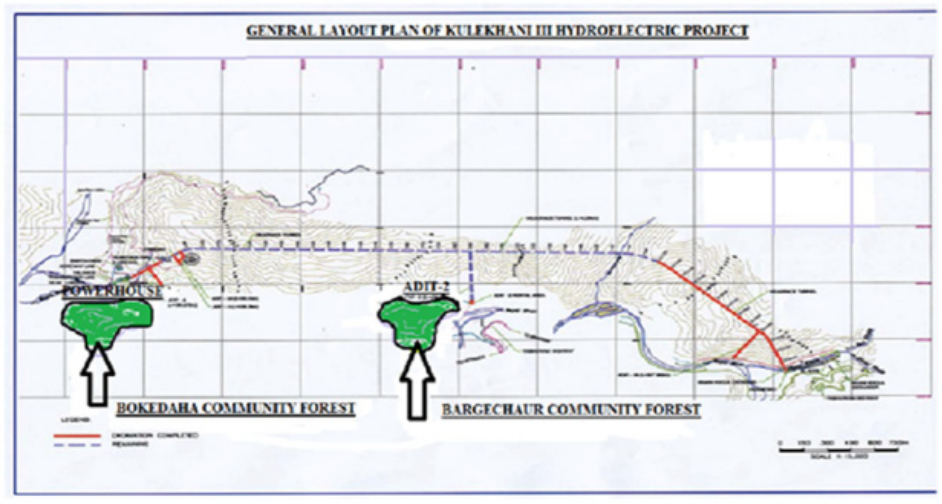

construction of Kulekhani III HEP were reviewed.

Delay in Slow Permitting and Forced Re-design

Construction of the initial access road was to begin in early 2008, but the employer encountered problems acquiring the land for the access road, which would ultimately lead to the connecting tunnel. This caused a two-year delay in road construction and forced the relocation of the tunnel to a second location known as Adit-2. However, apart from this delay, the contractor encountered more delays in obtaining permission to cut down trees for the access road. This caused an additional one-year delay. At the local level, local agitation against the project created additional delays. Locals were unhappy with the rates of compensation being offered for land acquisition.

Construction on the access road finally began in 2011 (NEA Report, 2014). The project was scheduled to be completed within 44 months (1,320 days) including mobilization, commissioning and testing. Due to the delay mentioned above, the contractor lost 1170 days, or $89 \%$ of the total estimated time for the project (MoA, 2012).

But let's look at that $89 \%$ more closely, especially in terms of money. The average power purchase agreement (PPA) rate for hydropower as offered by Nepal Electricity Authority per $\mathrm{kWh}$ is $6.6 \mathrm{NRs}$ for an

Figure 1: Map of study area

Kulekhani III HEP is a cascade project downstream of the original Kulekhani dam - the only storage project in Nepal, which has been providing peak energy to the Integrated Nepal Power System (INPS) since its construction. It is located in Makwanpur district in Bhainse Village Development Committee (VDC) of Narayani zone in Nepal, about $115 \mathrm{~km}$ south west of Kathmandu, the capital city of Nepal. The project utilizes the regulated flow from the Kulekhani reservoir and additional water from the Khani Khola (river). The total capacity of Kulekhani reservoir is 85,300,000 cumecs (NEA Report, 2014).

The powerhouse is located in Bokedaha Sanutar Community Forest. It was selected for the study of PES because the impact of project on the community forest and its users - 125 households in all, could be assessed. The Adit-2 portal tunnel and access road of the project lies in the Bargechaur Community Forest. This area was selected for same reasons with 138 households. Beneficiaries were selected for interview using a proportionate stratified random sampling method. To analyze questions about contract breaching, civil contractors were involved in discussion and employers were selected by using a purposive sampling technique.

\section{Results and Discussion}

In this section, various reasons behind the delay in annual energy production 40.85 GWh (ESSD, 2014). Thus, by calculating the loss of revenue for 1,170 days (or 3.2 years) following calculation can be obtained.

$=40.85 \times 10^{4} \times 10^{2} \times 3.2 \times 6.6 \mathrm{NRs}=\mathrm{NRs}$. $862,752,000.00$

\section{Payment Issue}

The payment to the contractor was not made according to the bill submitted by the contractor. The NEA deducted substantial amounts of money. These deductions are listed in Table 1.

\begin{tabular}{|c|c|c|c|c|}
\hline $\begin{array}{c}\text { IPC } \\
\text { No. }\end{array}$ & $\begin{array}{c}\text { Submitted } \\
\text { Amount (NRs.) }\end{array}$ & $\begin{array}{c}\text { Certified } \\
\text { Amount (NRs) }\end{array}$ & $\begin{array}{c}\text { Withheld } \\
\text { Amount (NRs) }\end{array}$ & $\begin{array}{c}\text { Withheld Per- } \\
\text { centage (\%) }\end{array}$ \\
\hline \multirow{2}{*}{11} & $32,840,608.68$ & $29,384,786.52$ & $3,455,817.16$ & 10.52 \\
& & & & 10.52 \\
\hline 12 & $17,366,774.00$ & $12,592,762.94$ & $4,774,011.06$ & 27.49 \\
\hline 13 & $48,832,569.48$ & $18,101,492.13$ & $30,731,077.35$ & 62.93 \\
\hline Total & $\mathbf{9 9 , 0 3 9 , 9 4 6 . 1 6}$ & $\mathbf{6 0 , 0 7 9 , 0 4 3 . 5 9}$ & $\mathbf{3 8 , 9 6 0 , 9 0 5 . 5 7}$ & $\mathbf{3 9 . 3 4}$ \\
\hline
\end{tabular}

Table 1: Payments Made by Employer to Contractor, Including Deductions
The table shows that the employer provided 39\% on the first three payments. The employer justified the income less amount of the total plete payment by saying that the contractor had not filed important documents such as the joint measurement sheet, a test report, and non-finalized new rate. From the study it could be said that the amount paid to the contractor by the employer was less than the billing amount submitted by the contractor. The withheld amount was $3.57 \%$ of the actual submitted total billing amount by the contractor. 
The total contract amount was NRs 1,092,502,035.00 (NEA Report, 2011).

The contractor (M/S Sino Hydro Corportation, China), defended its position, saying the engineer ordered two additional projects to be completed on a day work process that had not been included in the original Bill of Quantity (BoQ) (NEA Report, 2011). The first project was to carry out necessary diversion works in the Rapti river and to construct temporary river crossing so that heavy equipment could cross the river to the powerhouse site for excavation work. The second project called for the construction of a temporary road from the highway to the right bank of the Rapti River. The contractor completed both projects and filed the details of payment in Interim Certificate No. 4 in July 2009 (Table 2).

\begin{tabular}{|c|c|c|c|}
\hline $\begin{array}{c}\text { Claimed By } \\
\text { Contractor } \\
\text { (NRs.) }\end{array}$ & $\begin{array}{c}\text { Certified by } \\
\text { Engineer } \\
\text { (NRs.) }\end{array}$ & $\begin{array}{c}\text { Paid by Em- } \\
\text { ployer (NRs.) }\end{array}$ & $\begin{array}{c}\text { Deducted } \\
\text { Amount } \\
\text { (NRs.) }\end{array}$ \\
\hline 59258148.78 & 37662224.45 & 22753551.87 & 14908672.58 \\
\hline
\end{tabular}

Table 2: Contractor Interim Certificate, No. 4 Detailing Payment for Completed Work

The payment for this work was due November 11, 2009, but the employer did not complete the payment until September 30, $2011-688$ days late. The contractor claimed breach of contract. The employer explained its position noting the absent test report and the lack of proper approval from the employer for project variations undertaken by the contractor without the consent of the manager.

Late Selection of Electro-Mechanical Contractor Excavations of the powerhouse and tailrace were planned to start in July 2008 and to finish by the end of February 2009. The excavation of the powerhouse foundation was completed on March 5, 2009. However, the selection of an electro-mechanical contractor was finalized only in 2010 (NEA Report, 2014). As a result, the contractor could not obtain drawings and details for the powerhouse until October 2011. The employer blamed over-long bureaucratic procedures for gaining plan approval.

Again, viewed financially, there was a $60 \%$ time overrun due to the bureaucratic delays, which includes a loss of time for the contractor and a loss of saleable energy for the employer. Converting $40.85 \mathrm{GWh}$ into $\mathrm{kWh}$, where $40.85 \mathrm{GWh}$ is the annual energy production following two-step equation for net loss is obtained:

$40.85 \times 10^{4} \times 10^{2} \mathrm{kWh}=$ Loss of annual energy for 1170 days (2.16 years)

$$
\begin{aligned}
& 40.85 \times 1000000 \times 2.16 \mathrm{kWh}=88,236,000 \mathrm{kWh} \\
& =\text { NRs } 88236000 * 6.6 \\
& =\text { NRs } 582,357,600.00
\end{aligned}
$$

Issue of Varied Works under Clause 52.1, GCC During the construction process, the engineer determined the need of work that was not in the original contract, and so ordered that the contractor to do the work. The contractor undertook the work, despite the fact that the payment for this work could not be incorporated into its monthly billing certificate, and ready to lose those expenses. Furthermore, the new works ordered by the engineer were not evaluated by the employer, thus a provisional rate for payment could not be derived (NEA Report, 2011).

\section{Issues of Claim for Extension of Time (EoT)}

According to the contractor, they had raised claims for extension of time (EoT) to accommodate the new work requests by the engineer and employer. However, the EoT was not ultimately granted by the employer and those claims went unfulfilled (NEA Report, 2011).

\section{Condition Forwarded by the Contractor}

The contractor tried to terminate the contract after sending notice of suspension to the employer. The specific conditions were forwarded by the contractor to the employer in order to resume the works as follows:

\section{Extension of Time}

As per sub-clause of the contract document, works at connecting tunnel (later changed to Adit-2, which was on the critical path) in the baseline schedule, had been delayed by 38 months. From above condition it could be said that EoT was compulsory for contractor to resume their remaining works (NEA Report, 2014).

\section{Payment for all Completed Works}

As per contract document, employer was obliged to release all the withheld amount (NRs. 38,960,905.57 from IPC No.11, No.12, No.13 along with the deducted amount NRs. 14,908,672.58 from IPC No. 4) (MoA, 2012). Thus, on the basis of the information provided at site, it could be said that the employer had to pay altogether NRs. 53,869,578.15 combining withheld amount and deducted amount as compensation to the contractor (MoA, 2012).

\section{Prolongation Cost}

According to the respondents, prolongation cost was demanded by the contractor. It was based on the contract price without VAT and amounted to $30 \%$ of the price of the original contract equally distributed over period of 41 months to resume the works (MoA, 2012).

\section{Additional Cost}

According to the respondents, the contractor had demanded $65 \%$ payment in US\$ on the base date, and $35 \%$ in Nepali currency. The contractor was in danger being of blacklisted as he was unable to complete the project by internationally recognized corporation (MoA, 2012).

Problem Associated with the Contractual Issues
that were Addressed by the Project Management The notice of termination was forwarded to higher management. The legal steps were started from the legal documents. The options were compared whether it was beneficial to seek a new contractor or pursue negotiations with the existing contractor. Thus, formal letter was sent to the contractor for negotiation as it was beneficial in both aspects of time and cost. The project management made both the parties (employer and 
contractor) accept the MoA on February 18, 2012 (MoA, 2012). They agreed on the following points:

\section{Extension of Time}

As per the demand of Sino-Hydro Corporation, time extension of 30 months was given with the agreement made between both the parties.

\section{Demand for Payment}

Both parties agreed to discuss and evaluate item wise for certification of payment of all works meeting the specification requirements within one month after MoA had become effective.

\section{Prolongation Cost}

The contractor demanded the prolongation cost to be based on the contract price without VAT amounting to the $30 \%$ of the original contract equally distributed over the period of 41 months (MoA, 2012). Both parties agreed for prolongation cost to be $28 \%$ of the original contract price excluding VAT and to be equally distributed over the period of 30 months after resumption of works. In addition to above contractual issues that were addressed by the project management, the following understanding was also made by both the parties during the negotiation.

\section{Resumption of Works}

The work was resumed by the contractor within the period of 14 days upon the approval of the Memorandum of Agreement (MoA) by the employer. After MoA, the problem associated with the contractual issues was addressed by the project management using their nimble skill and past experiences. The problem was solved after the formation of a Dispute Resolution Board (DRB) comprising of experienced and intellectual members.

\section{Reasons for Time Extensions Required}

Based on interviews with contractors and clients, the reasons for time extensions required are listed in Table 3 .

\begin{tabular}{|c|l|c|c|}
\hline S.No. & $\begin{array}{l}\text { Cause for Suspension of } \\
\text { Civil Work in Adit-2 }\end{array}$ & Days & Percentage \\
\hline 1 & $\begin{array}{l}\text { Delay in issuance of variation } \\
\text { order }\end{array}$ & 891 & 76 \\
\hline 2 & Lack of tree felling permit & 119 & 10 \\
\hline 3 & Fault design by engineer & 90 & 8 \\
\hline 4 & $\begin{array}{l}\text { Unavailability of duty free } \\
\text { document }\end{array}$ & 60 & 5 \\
\hline 5 & Strike & $\mathbf{1 1 7 0}$ & $\mathbf{1 0 0}$ \\
\hline Total & & & \\
\hline
\end{tabular}

Table 3: Reasons for Time Extensions

Delays in the issuance of variation orders, the unavailability of duty free documents, and the lack of tree clearing permits are the managerial factors (MoA,2012). Faulty designs, which led to flooding problems, were technical issues. Local strikes against the project are the political. Together, these combined to create a delay of 1170 days (MoA, 2012).

\section{Interaction of PES Mechanism}

Turning now to PES, examination of guidelines in the construction of Kulekhani III HEP were done. Perceptions and challenges of PES for contractors, employers and local residents alike were noted.

Loss and damage of the flora and fauna was comparatively less than it was estimated before project implementation. The Environmental Impact Assessment (EIA) for Kulekhani III HEP predicted vegetation damage in the community forests due to site clearance, which was required for the intake site, and for the access roads to the dam (ESSD, 2014). Thus, estimated loss of vegetation before and after construction of project was evaluated to know the adverse effect of project implementation on environment.

\section{Perception of Local People Regarding Developmental Activities under PES}

A questionnaire survey was conducted with the members of the Bargechaur Community Forest to learn their perceptions towards Kulekhani III HEP. It was also conducted to understand if PES was providing effective assistance for the conservation of environmental services and helping to raise local awareness on these issues. Their responses to the development activities associated with the hydropower project are depicted in Figure 2, showing general satisfaction of the majority of respondents.

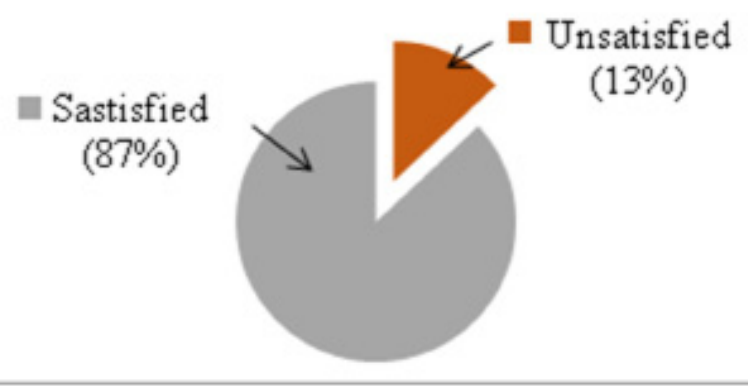

Figure 2: Perception of local people of Bargechaur Community Forest

These development activities included the construction of bridge over the Rapti River, local electrification, and construction of an access road, a drinking water facility, and an office building for the Bargechaur Community Forest Users Group. Similarly, the same type of survey was also carried out among local people of Bokedaha Community Forest in order to know about their perception regarding developmental activities.

Meanwhile, at the Bokedaha Community Forest, respondents were also satisfied with development activities associated with Kulekhani III HEP (Figure 3). At Bokedaha, these activities included an access road and other construction similar to those Bargatechaur. At Bokedaha, the access road to the powerhouse passes through the community forest. Thus, questionnaire survey was done regarding damage to the forest (Figure 4), compensatory planting and PES. Those responses are included in the figure below in terms of satisfaction or dissatisfaction. 
Comparison of Loss and Damage the vitality of the forest and its environmental services. of Post Construction Area vs. Regarding the compensatory plantation, the favorable Estimated Area before Construction

It was found that in Bargechaur Community Forest 1.56 hectares were affected against an estimate of 0.25 hectares. In Bokedaha Community, Forest, 2.64 hectares were affected against an estimate of 1.25 hectares (Figure 4).

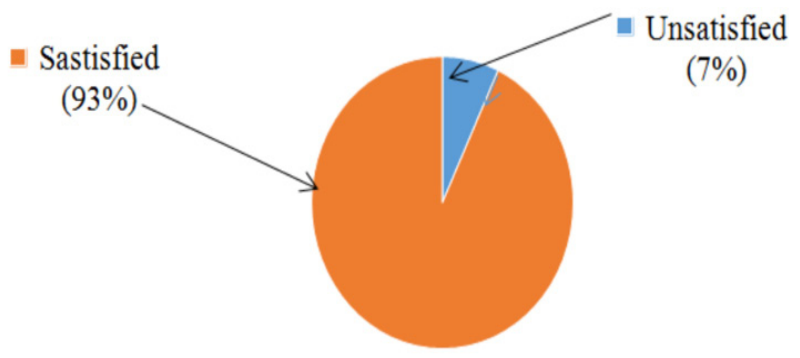

Figure 3: Perception of local people of Bokedaha Community Forest

\begin{tabular}{|c|l|c|c|c|}
\hline S.No. & $\begin{array}{c}\text { Project } \\
\text { Components }\end{array}$ & $\begin{array}{c}\text { No. of trees likely } \\
\text { to be felled }\end{array}$ & $\begin{array}{c}\text { No of trees } \\
\text { felled }\end{array}$ & Difference \\
\hline 1 & $\begin{array}{l}\text { Access road of } \\
\text { Powerhouse } \\
\text { of Bokedaha } \\
\text { community } \\
\text { forest }\end{array}$ & 250 & 499 & 249 \\
\hline 2 & $\begin{array}{l}\text { Dam and } \\
\text { reservoir }\end{array}$ & 143 & 0 & 103 \\
\hline 3 & Intake Site & 6 & 123 & \\
\hline 4 & $\begin{array}{l}\text { Adit I and II } \\
\text { of Bargechaur } \\
\text { community } \\
\text { forest }\end{array}$ & 20 & $\mathbf{6 2 2}$ & $\mathbf{3 5 2}$ \\
\hline 5 & Tailrace canal & 10 & 0 & \\
\hline Total & & $\mathbf{4 2 9}$ & & \\
\hline
\end{tabular}

Table 4: Comparative loss of vegetation from different components (NEPECON, 2003)
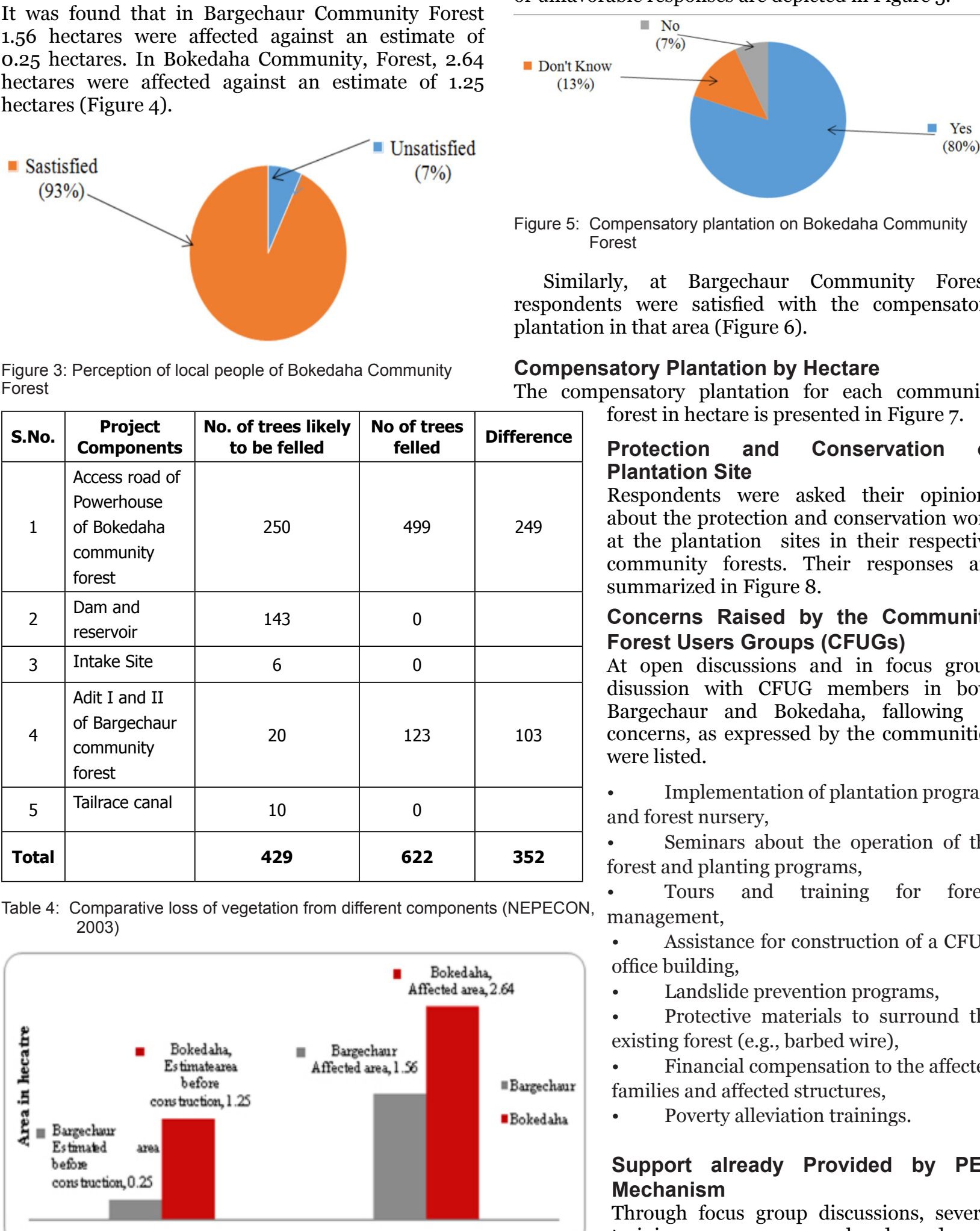

Figure 5: Compensatory plantation on Bokedaha Community Forest

Similarly, at Bargechaur Community Forest, respondents were satisfied with the compensatory plantation in that area (Figure 6).

\section{Compensatory Plantation by Hectare}

The compensatory plantation for each community forest in hectare is presented in Figure 7.

\section{Protection and Conservation of} Plantation Site

Respondents were asked their opinions about the protection and conservation work at the plantation sites in their respective community forests. Their responses are summarized in Figure 8.

Concerns Raised by the Community Forest Users Groups (CFUGs)

At open discussions and in focus group disussion with CFUG members in both Bargechaur and Bokedaha, fallowing of concerns, as expressed by the communities were listed.

- Implementation of plantation program and forest nursery,

- Seminars about the operation of the forest and planting programs,

- Tours and training for forest management,

- Assistance for construction of a CFUG office building,

- Landslide prevention programs,

- Protective materials to surround the existing forest (e.g., barbed wire),

- Financial compensation to the affected families and affected structures,

- $\quad$ Poverty alleviation trainings.

\section{Support already Provided by PES Mechanism}

Through focus group discussions, several training programs were already underway

Figure.4: Affected Community Forest

\section{Perceptions on Compensatory Plantation}

Compensatory plantatin was carried out after the project had cleared trees from the Bokedaha community forest. Compensatory plantation was undertaken to maintain in Bokedaha and Bargechaur. The respondents were generally happy with the programs and a considerable number of interested people were participating in the trainings. The variety of programs already held and the number of participants for each are summarized in Table 5 . 


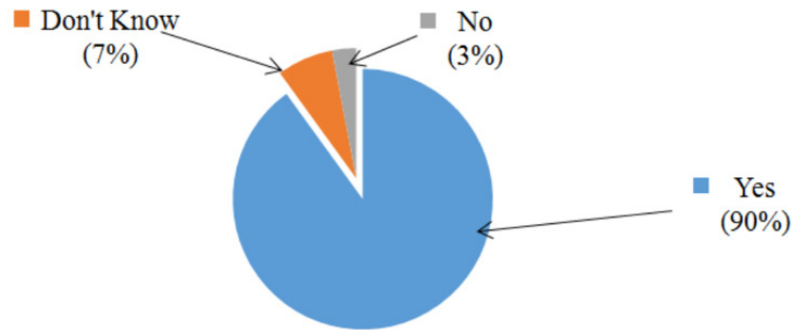

Figure 6: Compensatory plantation on Bargechaur Community Forest

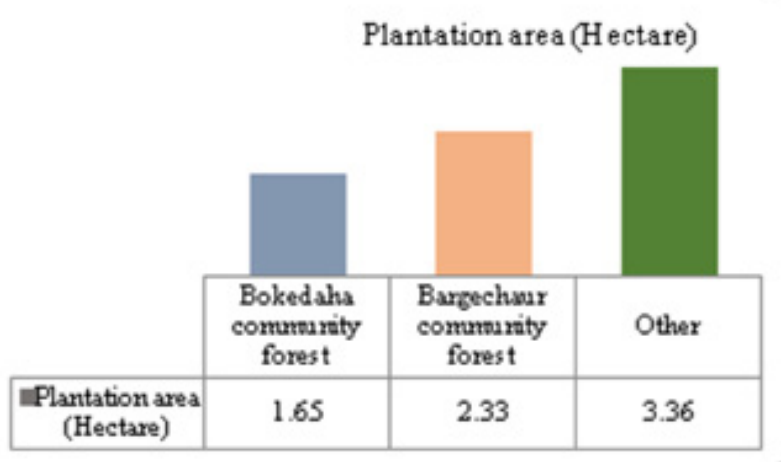

Figure 7: Compensatory plantation on affected areas (ESSD, 2014).

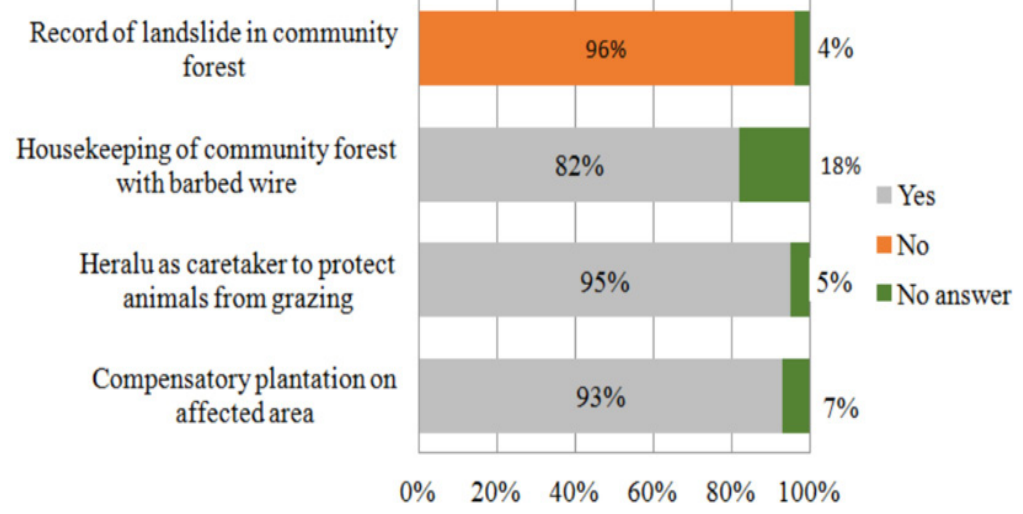

Figure 8: Protection and conservation of plantation site

\begin{tabular}{|c|l|c|}
\hline S. No & Training Title & Number of Participants \\
\hline 1 & Driving Title & 16 \\
\hline 2 & Computer Training & 20 \\
\hline 3 & $\begin{array}{l}\text { Social Awareness } \\
\text { Training }\end{array}$ & 25 \\
\hline 4 & $\begin{array}{l}\text { Forest Management and } \\
\text { wildlife Conservation } \\
\text { Training }\end{array}$ & 24 \\
\hline 6 & $\begin{array}{l}\text { Social Awareness } \\
\text { Training }\end{array}$ & 24 \\
\hline 7 & $\begin{array}{l}\text { Agricultural Productivity } \\
\text { Vegensification and }\end{array}$ & 20 \\
\hline
\end{tabular}

Table 5: PES programs and trainings already completed in association with K III HEP (ESSD, 2014)

\begin{tabular}{|c|l|l|c|}
\hline S. No & $\begin{array}{l}\text { Programs to } \\
\text { support Com- } \\
\text { munity }\end{array}$ & \multicolumn{1}{|c|}{ Location } & $\begin{array}{c}\text { Amount } \\
\text { (NRs). }\end{array}$ \\
\hline 1 & $\begin{array}{l}\text { Drinking water } \\
\text { supply }\end{array}$ & $\begin{array}{l}\text { Bhainse, Sikharbas, } \\
\text { Sanutar }\end{array}$ & 2.16 million \\
\hline 2 & $\begin{array}{l}\text { Community } \\
\text { building }\end{array}$ & Bokedaha, Sanutar & 0.93 million \\
\hline 3 & $\begin{array}{l}\text { River training } \\
\text { works }\end{array}$ & Bhainse, Sanutar & 1.94 million \\
\hline 4 & Training & Bhainse-1 & 0.49 million \\
\hline 5 & $\begin{array}{l}\text { Maintenance } \\
\text { Works }\end{array}$ & Bhainse-6 & 20.26 million \\
\hline 6 & $\begin{array}{l}\text { Financial Support } \\
\text { Makwanpur, } \\
\text { Sanutar }\end{array}$ & 1.78 million \\
\hline 8 & $\begin{array}{l}\text { Construction } \\
\text { works }\end{array}$ & Nibuwatar & 2.74 million \\
\hline Total & & Bhainse-7, Salghari & 2.51 million \\
\hline
\end{tabular}

Table 6: Construction and other activities planned or completed in association with the project (ESSD, 2014)

\section{PES-based Construction Activities Associated with Kulekhani III HEP During focus group discussions and interview with the Unit Chief of Environment Management Unit (EMU), of the project, following list of construction works that had been planned or already completed for community use in association with Kulekhani III HEP been noted. Also, the expense of each project has been noted in (Table 6).}

\section{Conclusion}

PES is relatively new concept enjoined to hydropower projects in Nepal, but our data show that it is having a positive impact in terms of satisfying local residents' needs and demands for livelihood, protection and compensation. PES not only holds the contractor to higher standards of environmental care but also provides incentives to local residents to play a more interested and constructive role in developing successful hydropower projects. In short, governmental agencies associated with hydropower (e.g., NEA, Ministry of Environment and Population, and the Ministry of Energy) are encouraged to work together more heartily in streamline permitting and payment processes for hydropower development. On the other hand, PES principles should continue to guide and shape the relationships between hydropower construction and local residents. There were many causes behind the delay of Kulekhani III Hydroelectric Project. However, permit for tree clearance for access road and untimely payment for contractors are the major ones. 


\section{Acknowledgements}

We would like to acknowledge Dr. Khem Raj Sharma, Prof. Ekku Pun, Mr. Robert Dangol, Er. Hari Mohan Shrestha, Er. Madhusudhan Pratap Malla, Mr. Megh Raj Rai, Er. Arpan Bahadur Singh, Mr. Anjay Mishra, Dr. N. K. Shrestha, Late Prof. Padam Bahadur Khadka, Dr. Rashila Deshar, Dr. Abhisek Yangkhrung Rai, Mr. Sanjeeb Bahadur Malla, Mr. Raju Gyawali, Er. Santosh Shrestha, Dr. Jhamak Karki, Mr. Sunil Kumar Dahal, V. K. Yadav and Er. Bir Bahadur Rai for their contribution during the preparation of this paper.

Khet Raj Dahal, PhD, is the principal of Lumbini International Academy of Science and Technology (LIAST), Lalitpur, Nepal. He completed his PhD from Kathmandu University in 2014 in the department of Environmental Science and Engineering, $M$. Sc. in Engineering from St. Petersburg University of Architecture and Civil Engineering in 1993, M. A in Sociology in 1999 from Tribhuvan University and M.Sc. in Ecology and Environment in 2004, from Sikkim Manipal University, Extension Centre, New Delhi. He is the winner of the best writer in environment in 2005 in Lumbini Zone, Nepal.

Corresponding E-mail: dahal.khetraj@gmail.com

Nabina Rai is an engineer in Gorkha Hydro and Engineering, Kathmandu, Nepal. She completed her Master of Science in Construction Management from Nepal Engineering College, Center for Post Graduate Studies in 2015.

E-mail: sabinanabina@gmail.com

\section{References}

Abu Ed, K.H., 2012. Investigation of Factors Affecting Termination of Construction of Contract in Gaza Strips. Masters Thesis. University of Gaza, Palestine.

CONTRACT ACT ,200o. The Act Amending Some Nepal Acts. Published on June 17, 2000.

Dessa, A., 2003. Claims in Ethiopian University. Masters Thesis. University of Addis Ababa, Ethiopia.

ESSD, 2014. Fourth Quarterly Environmental Monitoring Report of Kulekhani III Hydroelectric
Project. Environmental Monitoring Report. NEA.

Karmacharya, J.L., 2008. Maximizing Benefits from Hydropower: A Nepal Case. Available in Hydro Nepal Journal, www.nepjol.info/index.php. Accessed in Jan 12,2015.

Khanal, R. \& Paudel, A., 2012. Payment for Ecosystem Services (PES) schemes for Conserving Sardu Watershed Nepal. Working Paper no. 3. International Union for Conservation of Nature (IUCN), pp. 12-18.

Khatri, D.B., 2009. Payments for Ecosystem services in Kulekhani Watershed of Nepal: An institutional analysis of mechanisms for sharing hydroelectricity revenue. Masters dissertation. Institute of Social Studies, Netherlands.

Mahamid, I., 2011. Causes of Contractors' Failure: Contractors' View. 2nd International Conference on Construction and Project Management IPEDR.,Singapore.

MoA Document,2012. Memorandum of Agreement, an official document of Kulekhani III Hydroelectric Project, NEA, Bhainse, Makwanpur, , Feb 18,2012.

NEA Report, 2011. Notice of Suspension, an official document of Kulekhani III hydroelectric Project, NEA,Nov 13,2011, KL-III/EPY/224, Bhainse, Makwanpur.

NEA Report, 2014. Project Report of Kulekhani III Hydroelectric Project, an official document of Kulekhani III hydroelectric Project, NEA, Nibuwatar, Makwanpur.

NEPECON, 2003. Environmental Impact Assessment Report of Kulekhani III Hydroelectric Project. Prepared by NEPECON,Ltd, Dip Consultancy (P).

Pandey, B.,2013. Status of Hydroelectricity in Nepal: Potential and Challenges. Available in www. binodpandey.wordpress.com. Accessed in July 15, 2014.

Wunder, S., 2007. The Efficiency of Payments for Environmental Services in Tropical Conservation. Biological Conservation 21:48-58.

WWF, 2006. Payments for Environmental Services An equitable approach for reducing poverty and conserving nature. Report for a living planet, 2006. 